Hakan Kırımlı and Ali Yaycıoğlu*

\title{
Heirs of Chinghis Khan in the Age of Revolutions: An Unruly Crimean Prince in the Ottoman Empire and Beyond
}

https://doi.org/10.1515/islam-2017-0029

\begin{abstract}
Focusing on Cengiz Mehmed Geray, an idiosyncratic member of the ruling house of the Crimean Khanate, this article examines how a Crimean Prince became an active participant in the stormy politics of the Ottoman Empire and later of Europe, as a result of his distinguished Chinghisid pedigree, in the age of revolutions. The first section of this article discusses the place of the Geray and Chinghisid lineage within Ottoman imperial politics. The second section focuses on the period following the Gerays' departure from Crimea. It illustrates how members of the family, although scattered throughout the Balkans, operated in the provincial and imperial politics of the Ottoman Empire in the late 18th and early 19th centuries. The following section introduces Cengiz Geray and his turbulent life between the Ottoman and Russian Empires, and discusses how he became an actor in a revolutionary age. The last section is a short discussion on Chinghisid charisma in the early modern Europe, Russia and the Ottoman Empire.

Keywords: Ottoman Empire, Crimean Khanate, Russia, France, Balkans, Gerays, Chingis Khan, Napoleon, French Revolution, Cengiz Mehmed Geray, Osman Pazvantoğlu
\end{abstract}

\section{Introduction}

We do not know whether Napoleon considered Cengiz Mehmed Geray Sultan (hereafter Cengiz Geray) a viable candidate to the Ottoman throne in 1801, when he received a letter implying that Cengiz Geray could play a major role after a possible removal of the Ottoman dynasty. Cengiz Geray was a member of the Geray house of Crimea. In Ottoman circles, the Gerays, the ruling dynasty of the Crimean Khanate, had long been considered, albeit not openly, a possible alternative to the throne of the Sublime Porte, should the Ottoman family be extinguished. In

\footnotetext{
*Corresponding authors: Hakan Kırımlı, Bilkent University, Ankara, Turkey, kirimli@bilkent.edu.tr; Ali Yaycıoğlu, Stanford University, Stanford, USA, ayayciog@stanford.edu
} 
the late 18th and early 19th centuries, when Ottoman integrity was at stake in the Balkans, the Gerays participated in restructuring the new order. Focusing on Cengiz Geray, an idiosyncratic member of the family, this article examines how a Crimean Prince became an active participant in Ottoman provincial politics and later European diplomacy, as a result of his distinguished status.

The Geray dynasty was genealogically linked to Chinghis Khan through his son, Jochi. Following the dismemberment of the Golden Horde Empire in the early 15th century, the House of Geray was among a number of dynasties, which inherited its patrimony and claimed Crimea. The Gerays ruled the peninsula and its vast hinterland as the Crimean Khans until 1483. From 1475 to 1478, the Crimean Khan Meñli Geray I (1445-1515) accepted the suzerainty of the Ottoman Sultan, Mehmed II (1432-1481). Beginning in the 15th century and until 1783, members of the Geray dynasty gained a distinctive status within the Ottoman imperial hierarchy and played important roles in both domestic and inter-imperial politics. While the Khanate had a strategic function as a frontier power for the Ottomans against the Muscovite State, Poland-Lithuania, and Safavid Iran, members of the Geray family sometimes acted as obedient members of the Ottoman imperial elite, sometimes as allies and sometimes as unruly vassals of the empire. ${ }^{1}$

In 1783, when Russia annexed Crimea, virtually all members of the Geray house left their homeland and most of them immigrated to the Ottoman Balkans, where they already had estates that the Ottoman sultans had granted them. In the late 18th and early 19th centuries, the Gerays spread out in the Balkans and became integrated into local life in the region. Cengiz Geray was one of these family members. After participating in the war against Russia in the Ottoman army, he then turned against the Ottoman central government. Upset because his estate was confiscated, Cengiz Geray gathered an armed militia and challenged the Ottoman state. Declared a rebel, he fled to Russia where he was honorably received as a member of the royal family in defiance of the Ottoman Empire. When Cengiz Geray returned to the Balkans, he became an ally of Osman Pazvantoğlu, a powerholder in Ottoman Bulgaria. Pazvantoğlu dragged Cengiz Geray to become a co-player in a plan submitted to Napoleon. According to the proposal, Cengiz Geray would become a ruler of a newly created kingdom consisting partially, perhaps entirely, of Ottoman lands. Cengiz Geray's case illustrates the political

1 Halil İNALcıK, “Giray,” $E P^{2}$, vol. 2, Leiden: Brill, 1965: 1112-1114; idem, "Yeni vesikalara göre Kırım hanlığının Osmanlı tâbiliğine girmesi ve ahidname meselesi,” Belleten 8 (1944): 185-229; Dariusz Koєodziejczyк, The Crimean Khanate and Poland-Lithuania: International Diplomacy on the European Periphery (15 $15^{\text {th }} 18^{\text {th }}$ Century). Leiden: Brill, 2011. 
dynamics of the time; an upset and disobedient Crimean prince turned out to be a challenger to the Ottoman Empire and gradually became an inter-imperial actor in this age of unpredictable transformations.

\section{The Chinghisid Lineage and the Gerays in the Ottoman Political Culture}

In the Islamic world, the heritage of the empire of Chinghis Khan is a complex phenomenon. Contemporary Muslim historians depicted the Mongol conquests of Muslim lands in the 13th century as a cataclysmic event. However, after the Islamization of the Mongol ruling elite of the Ilkhanid, Chaghatay, and Golden Horde Empires, Muslim historians revised the demonic image of the Chinghisid heritage. $^{2}$ In the late 13 th and first half of the 14 th centuries, while Islamic lands were incorporated into a broader Mongolian Eurasian system, Mongol elites began integrating into Muslim establishments. Meanwhile, the Mongol ruling elite soon became fully assimilated among the majority Turkic population in much of the Chinghisid Empire, notably and most characteristically in the Golden Horde. Gradually, Mongol political and administrative conventions, such as yasa (Mongol law) and tamgha (commercial taxes), were integrated into the Islamic institutional repertoire. After the disintegration of the Mongol order in the second half of the 14th century in Western and Central Asia, ${ }^{3}$ new polities formed under the leadership of Turkic warriors, such as the Ottoman principality and the Timurids, who employed Turco-Mongolian political concepts, including the imperial title of Khan, as a legitimate entitlement. The Chinghisid lineage became a supreme pedigree, competing with the lineage of the Quraysh and Bani Hashim, the tribe and clan of the Prophet Muhammad, as a source of legitimacy. ${ }^{4}$

2 Devin DeWeese, "Islamization in the Mongol Empire," in The Cambridge History of Inner Asia: The Chinggisid Age, ed. N. Di Cosmo, A. J. Frank and P. B Golden. Cambridge: Cambridge University Press, 2009, 120-134.

3 Linda Komaroff and Stefano Carboni, eds., The Legacy of Genghis Khan: Courtly Art and Culture in Western Asia, 1256-1353. New Haven: Yale University Press, 2002; Linda KomARoff, "Introduction," in Beyond the Legacy of Genghis Khan, edited by L. Komaroff and S. Carboni, Leiden: Brill, 2006, 1-10; N. Di Cosmo, A. J. Frank and P. B. Golden, "Introduction," in The Cambridge History of Inner Asia: The Chinggisid Age, ed. N. Di Cosmo, A. J. Frank and P. B. Golden. Cambridge: Cambridge University Press, 2009, 1-6.

4 Jean AuBin, Emirs mongols et vizirs persans dans les remous de l'acculturation, Paris: Association pour l'avancement des études iraniennes, 1995; John Andrew BoyLE, “The Thirteenth-Century Mongols' Conception of the After Life: the Evidence of their Funerary Practices," Mongolian 
After the disintegration of the Ilkhanid and Golden Horde empires in the late 14th and early 15th centuries, Timur (who was not Chinghisid himself but married a Chinghisid princess) claimed to act on behalf of a puppet Chingisid khan, and reasserted the empire of the House of Chinghis in Iran and Central Asia. In 1402, Timur put an end to the newly formed Ottoman Empire in Anatolia and the Balkans, partitioning the Ottoman realm among the sons of the defeated Ottoman sultan, Bayezid I. Although the empire was re-unified in 1411 under Mehmed I, the Ottoman dynasty was struck by a major legitimacy crisis against the Chinghisid proclamation. The challenge by Timur pushed some Ottoman historians in the 15th century to emphasize the connections between the Ottoman dynasty and the Oghuz Khan, a legendary founder of the Turkic Confederation in Pre-Mongolian Central Asia. Only after the conquest of Constantinople by Mehmed II in 1453 and the incorporation of Mecca and Medina into the Ottoman realm in 1518, the Ottoman dynasty acquired self-confidence vis-à-vis the Chinghisid and other (ancient or contemporary) Muslim dynasties and pedigrees. Over the centuries, however, the shadow of Chinghis Khan continued to loom over Ottoman politics. ${ }^{5}$

In 1475, the Crimean Khan Meñli Geray, who claimed the realm of the Golden Horde, approached the Ottomans and accepted the suzerainty of Sultan Mehmed II. Mengli Geray's acceptance of Mehmed's suzerainty was probably articulated in an agreement between the two emperors. Although we do not know the details, Ottoman and Crimean sources referred to this epic moment, which later formed the basis of the special status of Crimea and the Gerays in the Ottoman Empire. ${ }^{6}$ Between 1475 and 1774, Crimea was a vassal state, ruled by the Gerays, under the Ottoman imperial umbrella. Despite this status, the Crimean

Studies 1 (1974): 5-14; Charles Melville, "Pādshāh-i Islām: the Conversion of Sultan Maḥmūd Ghāzān Khān," in History and Literature in Iran: Persian and Islamic Studies in Honour of P.W. Avery, edited by Charles Melville, London: British Academic Press, 1990: vol. 1, 159-177; 'Alā' al-Dīn 'Ațā Malik Juwaynī, Genghis Khan: the History of the World Conqueror, translated by J.A. Boyle, Manchester: Manchester University Press, 1997.

5 Cornell H. Fleischer, Bureaucrat and Intellectual in the Ottoman Empire: Historian Mustafa Âli, Princeton, NJ: Princeton University Press, 1986, 273-291; Halil İNALCik, "Power Relationships between Russia, Crimea, and the Ottoman Empire as Reflected in Titulature," in Passé Turco-Tatar présent soviétique: Études offertes à Alexandre Bennigsen, ed. Ch. Lemercier-Quelquejay, G. Veinstein and S. E. Wimbusch, Paris: EHESS, 1986, 175-211; Baki TezCAN, "The Memory of the Mongols in Early Ottoman Historiography," in Writing History at the Ottoman Court, ed. E. Çıpa and E. Fetvac1, Bloomington, IN: Indiana University Press, 2013, 23-38.

6 Halil İNALCıK, "Yeni vesikalara göre Kırım hanlığının”; Akdes Nimet KuRAT, Topkapı Sarayı Müzesi Arșivindeki Altın Ordu, Kırmm ve Türkistan Hanlarna Ait Yarlı ve Bitikler, Istanbul: Burhaneddin Matbaas1, 1940, 88-89. 
Khanate never abandoned its identity and prerogatives, including its claim over the entire realm of the former Golden Horde.

From mid-16th century on, the alliance between the Crimean Khanate and the Ottoman Empire, gradually evolved into a peculiar vassal-suzerain relationship with strong symbiotic ties. On the one hand, the Crimean khans had recourse to the Ottoman military might, particularly its advanced artillery against their external enemies. Backed by the Porte, the khans now had a firmer standing visà-vis the political challenges of the Crimean feudal beys at home. This being the case, however, the khans' fate on the throne in Bahçesaray, the capital of the Khanate, was determined by the Porte, which could depose the ruling one and ascend another at any time at will. The presence of tens of members of the Geray dynasty residing in the Ottoman Empire only helped this practice. However, the Crimean troops with legendarily proficient and swift mounted archers provided the Ottoman army with a crucial auxiliary force for forays into the rear of the enemy. From the first half of the 16th century to the end of the 18th, the Crimean cavalry invariably accompanied the Ottoman army in every major war. Moreover, in the course of these times, the Crimean Khanate played the role of a solid barrier against any threats from the north towards the Ottoman-held Black Sea basin. Not surprisingly, throughout this intricate relationship between these two states, their politics were also inextricably entangled through alliances, connections, patronage relations, intrigues, and maneuvers involving the notable personages and factions in Istanbul and Bahçesaray. ${ }^{7}$

According to convention, the Ottoman sultan appointed a khan by dispatching an imperial diploma with drums and banner, the imperial insignia of the sovereign Ottoman sultan granted to his vassal ruler. ${ }^{8}$ But the place of the khans in Ottoman political culture was far more complex than a simple vassal-ruler relationship. The Ottomans recognized that the Crimean khans had the right to mint coin bearing their names. They also had Friday sermons delivered in the mosques of Crimea, honoring them as rulers of the land as signs of sovereignty. The khans used not only the Chinghisid title of khan, but also designations borrowed from Islamic and Ottoman traditions, such as sultan and padishah. Apart from the Ottoman ruler, male members of the Geray house were the only hereditary and legitimate bearers of the title "sultan." Their distinctive standing was

7 For a recent edited volume on the history of the Crimean Khanate, see Denise Klein, ed. The Crimean Khanate between East and West, Wiesbaden: Harrassowitz Verlag, 2012. For the Khanate's role in international diplomacy, see Dariusz Kolodziejczyк, The Crimean Khanate and Poland-Lithuania.

8 Cemal Kafadar, Between Two Worlds: The Construction of the Ottoman State, Berkeley, CA: University of California Press, 1995, 146-147. 
also recognized in Ottoman imperial ceremonies. When khans visited Istanbul, they enjoyed a position equal to the Grand Vizier and second only to the Sultan in Ottoman protocol. ${ }^{9}$

Beginning in the 17th century, many khans were incorporated into the Ottoman establishment. The majority of the Gerays spent time on their estates with handsome annual incomes in the Ottoman Balkans, waiting for their turn to become Khan or lesser dignitaries in the khanate. Meanwhile, the Ottoman center became involved in the affairs of the northern frontier as a response to the consolidation of the Russian Empire. Persistent interventions by Ottoman authorities in the affairs of Crimea irritated the Crimean elite, who thought the khans were, if not equals, then subordinate peers of the Ottoman sultans. ${ }^{10}$ In the early 18 th century, the Crimean historian, Mehmed Geray (d. after 1703), a Geray himself, openly criticized the Ottoman practice of constantly deposing khans without justification. He proposed: "a Muslim padişah should not be deposed [by another Muslim padişah]. He should be investigated. If a fault was certain, he should be adjudicated according to the sacred law."11

This was also the period when the Gerays received more frequent mentions in Ottoman circles as an alternative to the Ottoman dynasty. According to a 17th-century Ottoman source, a story set in the early 15th century depicted the challenge of a Geray Khan to an Ottoman Sultan: The Crimean khan claimed the throne from the Ottoman Sultan Murad II (1404-1451) on the basis that the Gerays, as a Chinghisid dynasty, were older and therefore superior to the Ottomans. Instead, Murad, who intended to prevent a war between two Muslim emperors, proposed a one-on-one wrestling match to the Khan. Murad and the Khan wrestled. The Ottoman sultan beat the Khan and was able to keep his throne. This story echoes the 15th-century interregnum after Timur defeated the Ottomans. But the story can also be understood as evidence that in different circles in the 17th century, the Gerays were considered as challengers to the Ottomans. ${ }^{12}$

\footnotetext{
9 Halil İNALCIK, "Power Relationships between Russia, Crimea, and the Ottoman Empire as Reflected in Titulature”, Paris, 1986, 175-211.

10 Alan Fisher, "Crimean Separatism in the Ottoman Empire," in Nationalism in a Non- National State: The Dissolution of the Ottoman Empire, ed. W. W. Haddad and W. Ochsenwald, Columbus: University of Ohio Press, 1977, 57-67; the article is republished in Alan FISHER, Between Russians, Ottomans and Turks: the Crimea and Crimean Tatars, Istanbul: Isis Press, 1998, 67-78. 11 Mehmed Geray, Tarih-i Mehmed Geray, Ms: Österreichische Nationalbibliothek, Vienna, no. 1080: 12a; Uğur DEMIR “Tarih-i Mehmed Giray, Değerlendirme - Çeviri Metin,” Unpublished MA thesis, Marmara University, Istanbul, 2006, 15; Denise KLEIN, "Tatar and Ottoman History Writing," in D. Klein, ed. The Crimean Khanate between West and West (15 $15^{\text {th }} 18^{\text {th }}$ Century), 134-142.

12 Feridun M. Emecen, “Osmanlı Hanedanına Alternatif Arayışlar Üzerine Bazı Örnekler ve Mülahazalar,” İslâm Araştırmalan Dergisi (Istanbul) 6 (2001): 66.
} 
As far as we know, Ottoman historians never formally acknowledged the Gerays as an alternative to the Ottoman dynasty. However, in some sources, including official chronicles, pieces of various anecdotes suggest this possibility. Particularly during political crises and popular unrest, the idea of replacing the Ottomans with the Gerays was openly expressed. If one reason was opposition to different Ottoman sultans or the court in general, another might stem from the fact that male heirs of the Ottoman dynasty were always few because of the earlier practice of fratricide. The possibility that the Ottoman lineage might die out must have kept rumors alive that mentioned the Gerays as a substitute dynasty. According to an anecdote, in 1614, Sultan Ahmed I went hunting. When he sent off his falcon, he saw another snatching away the bird his falcon intended to catch. The Sultan learned that the owner of the thief was Mehmed Geray, a Crimean Prince, whom the Grand Vizier, Nasuh Pasha, invited to the hunt. The Sultan was told that Nasuh intended to replace Ahmed I with the Geray. Ahmed I then ordered to have Mehmed Geray imprisoned in Yedi Kule, the famous jail in Istanbul. ${ }^{13}$ Three years later, Mehmed Geray would escape during the celebration of Osman II's accession and became the khan in 1623.

Around that time, during incidents that resulted in the deposition and slaying of Osman II in a Janissary-led revolt in 1622, sources noted that the Grand Vizier Davud Pasha intended to extinguish the Ottoman family and put the Crimean Khan on the throne. ${ }^{14}$ Again, in the 17th century, rumors circulated that before dying, Murad IV intended to execute his brother Prince İbrahim, the only heir to the throne, and enthrone either his close friend Mustafa Pasha or Bahadir Geray, the khan of Crimea. ${ }^{15}$ In 1640 or 1641, Şahin ("Hawk") Geray, was executed during his stay in Rhodes on the basis of a prophecy that someone with a name of a bird would terminate the Ottoman house. ${ }^{16}$ During the revolt, which resulted in the toppling of Mehmed IV (r. 1648-1687), observers recorded that some insurgents declared their wish to slay all princes and members of the Ottoman family and replace the Ottoman dynasty with the Gerays. ${ }^{17}$

During this period, an eccentric Sufi sheikh, Niyazi-i Misrî (1618-1693), wrote in his biographical cri de coeur: "Before I die, let me tell my will. The throne belongs to the Tatar [Crimean Khan]; the throne belongs to the Tatar; the throne belongs to the Tatar. They [the Ottomans] failed to be corrected. They are like a rotten egg.

13 Ibid, 69-70.

14 Ibid, 69.

15 Feridun M. Emecen, “İbrahim,” Türkiye Diyânet Vakfi İslâm Ansiklopedisi, vol. 11, Istanbul: Türkiye Diyânet Vakfı, 1995, 274-281.

16 Naima Mustafa Efendi, Târih-i Na'îmâ, edited by Mehmet İpşirli, Ankara: TTK, 2007, 946.

17 Silahdar Findıklılı Mehmed Ağa, Silahdar Tarihi, vol. 2, Istanbul: Devlet Matbaası, 1928, 340. 
There is no more goodness in them. The throne will go to the Tatar."18 Misrî saw the Gerays as true and just Muslim rulers who would replace the "deviant" Ottomans on the throne of the empire. Misrî's remarks were uttered in an age when evangelical movements posed purported challenges to the religious orientations of members of the imperial elite by claiming insufficient Muslim purity. Misrî’s glorification of the religious dignity of the Gerays against the Ottomans also denoted a change in the perception among the Muslim learned circles. The descendants of Chinghis Khan were no longer associated with the horrifying memory of their ancestors who had sacked Baghdad and executed the Abbasid caliph in 1258.

In the late 18th and early 19th centuries, other cases appear where Gerays were viewed as possible candidates for the imperial throne. The shadow of Chinghis Khan endured in the Ottoman world, resurfacing on occasions when the fate of the Ottoman dynasty was in jeopardy as a result of political or dynastic crises. But there is no evidence that elites who promoted the Gerays as an alternative harbored a political agenda based on the superiority of the Gerays over the Ottomans. In fact, there is also no evidence that the Chinghisid lineage constituted an open threat to the Ottomans after the mid-15th century. Nor is there substantiated proof that the Gerays were even interested in taking the throne of the Ottomans. Still, these scattered anecdotes provide us with reasons to believe that the Crimean Gerays were the first family that entered into the minds of those considering dynastic change. Both the legacy and memory of Chinghis Khan and the distinctive status of the Gerays in the Ottoman political system provided a legitimate case for the Gerays as an alternative dynasty for some in the empire.

\section{The Gerays in the Ottoman Balkans}

After the Russian annexation of the Crimea in 1783, as Catherine II was carving out a new Russian province from the peninsula, most members of the Geray house and leading Crimean notables emigrated to Rumelia, namely the main Ottoman province in the Balkans that included present-day Bulgaria, Turkish Thrace, Northern Greece, and Macedonia. ${ }^{19}$ Since the Ottomans cherished hopes of recovering the Crimea, they considered the Gerays a political card for their

18 Halil ÇEÇEn, Niyazî-i Mısrî’nin Hatıralan, Istanbul: Dergah, 2006, 35.

19 Ali KaraCA, “Giraylar (1440-1840),” Bir (Istanbul) 7 (1997): 95-100. For the Gerays in present-day Bulgaria, see: Petr MiıATEv, "Potomki krymskikh Gireev i ikh gospodstvo v nekotoryh chastiakh Bolgarii v XVII-XIX vv.,” Uchennye zapiski Instituta Slavianovedeniia, vol. 16, Moscow, 1958, 288-303; Stoian Antonov, Tatarite v Bylgariia, Dobrich, 2004, 43-50. 
policy towards Russia. Accordingly, dozens of Gerays were reorganized in the Balkans into a dynastic network in exile. The Ottomans appointed one from the group, possibly a former khan or a senior Geray, as representative (Sahibü'l-arz) of the dynasty. This person would be responsible for the affairs of the Gerays in the Ottoman realm. In wartime, one Geray acted as "Tatar Commander," commanding the armed forces composed of Crimean Tatars. Several Crimean royal ranks, including qalgay and nureddin, continued to be granted. ${ }^{20}$

In the last quarter of the 18th century, the Balkan provinces, where the Gerays had been integrated, experienced a profound transformation. Throughout the 18th century, various notable individuals and families, who were commonly known as âyans, were gaining control in the Ottoman Balkans. On the one hand, these powerholders competed with one another for wealth and power. On the other hand, they acted as brokers between local communities and the central administration. In several regions, Muslim and Christian militia, known as the dağll (the mountaineers) or kurcall provided these local notables with armed forces. In fact, it was not unusual for the chiefs of the mountaineers to transform into local notables, by securing communal acceptance as protector and/or by acquiring mercy and then office from the Ottoman Court. Gradually, the central authority became dependent on these newly established notables for collecting taxes and maintaining order, on account of their connections to local communities, monopoly over local resources, and their growing financial power. Although the central authority occasionally attempted to eliminate some of these local powerholders through exiles, executions or confiscations, officials in Istanbul often conceded to the regional status quo and maintained supremacy only by supporting one notable against another thus preventing them from uniting forces. ${ }^{21}$

Although the Gerays were transplanted figures in the Balkans, they lived like other local powerholders in this environment. The Gerays held already estates scattered across the region since the 16th century. But until the Russian annexation of Crimea, they considered their stay in the Balkan countryside temporary. After 1783, however, the Gerays found themselves in the region for good. Using the prestige of their pedigree, some of the Gerays expanded their power beyond the boundaries of their estate and claimed the surplus from communities in the vicinity of their estates. ${ }^{22}$ Some of the Gerays were involved in power struggles and competition with other notables in their respective regions. Others offered

20 Başbakanlık Osmanlı Arşivi - Istanbul/Prime Ministry Ottoman Archives - Istanbul (Hereafter to be cited as BOA), CA 29/1327; BOA, CA 29/1325 and CH 65/3243.

21 Ali YaycioĞLu, Partners of the Empire: The Crisis of the Ottoman in the Age of Revolutions, Stanford: Stanford University Press, 2016, 65-115.

22 BOA, CH 42/2077. 
shelter to mountaineers and employed them as armed militia. In sum, by the end of the 18th century, the Gerays simultaneously played the roles of local notables and an outside royal dynasty in the Ottoman Balkans. ${ }^{23}$

\section{The Story of Cengiz Mehmed Geray}

Although it is not clear where Cengiz Geray spent his life prior to the second half of the 1770s when he was settled in Rumelia, we know that Cengiz Geray's genealogy indicates that he was a Crimean prince belonging to the line of direct succession. ${ }^{24}$ Since he is known to be related to the Circassian (Adige) tribes, ${ }^{25}$ either his mother or godmother must have been a Circassian, and he probably spent some time in his early life with that tribe in the Caucasus. There, he must have trained as a warrior and would-be khan, in accordance with the old tradition of atalıq. ${ }^{26}$ Cengiz Geray's connections to the Circassian tribes would later provide him with safe haven when fleeing from the Ottoman lands.

Sometime in the second half of the 1770s, at the peak of Russian intervention in Crimea, Cengiz Geray and his three brothers settled in Shumen (in today's Bulgaria). ${ }^{27}$ While Cengiz Geray resided in the village of Vyrbitsa, his brothers Bahadır, İslâm, and Meñli were in neighboring villages. ${ }^{28}$ Vyrbitsa was the estate of the direct forefathers of Cengiz Geray and his brothers since at least the preceding century. ${ }^{29}$ The Geray brothers established themselves in their estates in these villages and became part of local politics. We can follow their activities through

23 BOA, CZ 34/1661; BOA, CEM 8/367; Ahmet HEZARFEn, Rumeli ve Anadolu Âyan ve Eşklyasl. Osmanh Arşiv Belgeleri, Istanbul: Kaynak, 2002 [Hereafter to be cited as HeZARFEn I], 140-141, 136-137, 220-221.

24 BOA, CH 58/2859. He was the son of Mesud Geray and grandson of Arslan Geray Khan. The latter occupied the Crimean throne during the years 1747-1756 and 1767: Halim Geray, Gülbün-i Hânân, Istanbul, 1287 [1870], 103-109.

25 The Adige tribe which he was related to must have been the Temirgueys (Kemirgueys) amidst whom he would go in 1798 from Russia, whence he had fled six years previous. BOA, CH 26/1251. 26 The atal $q$ custom was about sending ceremoniously every male member of the Geray dynasty, having reached a certain age of childhood, to a Circassian noble family to be brought up in the virile arts of tough North Caucasian life.

27 Local Ottoman documents pertaining to the year 1792 accused Cengiz Geray and his brothers of patronizing brigands in the Balkans for fifteen years. BOA, CH 93/4611; BOA, CD 116/5797; Ahmet Hezarfen, Rumeli ve Anadolu Âyan ve Eşkyyast-2. Osmanh Arşiv Belgeleri, Istanbul: Kaynak, 2004 [Hereafter to be cited as HeZARFEN II], 319.

28 BOA, CD 116/5797.

29 Miratev, 291 and 293. 
grievances by local villagers and notables that were presented in regional courts or sent to Istanbul. Locals claimed that the brothers manipulated elections for district âyâns. ${ }^{30}$ According to these complaints, one family member (probably Cengiz Geray) placed his candidate in the post of the âyân of Osmanpazar1. The governor of Silistra interfered and deposed the âyân. ${ }^{31}$ In many cases, their reputation also furnished local brigands or members of the communities with protection or patronage. The family established close connections to local elites through marriage. Cengiz Geray married the daughter of a local notable, the âyân of Tirnova (Veliko Tărnovo). The family, however, did not compete to be âyân since their higher status did not allow for the acquisition of such low-ranking administrative posts. Rather, the Gerays preferred to intervene in local politics behind the scenes, through figures they backed. Their constant meddling challenged several local notables and community leaders who derived power not from their pedigree, but from tax-collection and community leadership.

\section{War}

In 1789, during the war between the Ottoman Empire and the Russian and Austrian coalition (1787-1792), an imperial decree, personally addressed to 36 Gerays, was disseminated across the Balkans. It called Cengiz Geray and his brothers to arms. The men were asked to assemble their forces under the command of Baht Geray, who had been declared "Khan of Kuban" and commander of Tatar forces, and to mobilize troops in the port city of İsmail/Izmail. ${ }^{32}$ Cengiz Geray fought in Yergöğü/Giurgiu, the critical Ottoman stronghold on the northern banks of the Danube against the Austrian troops. According to a document, Cengiz Geray acted gallantly, defending the fortress despite the city's vulnerable position against a large Habsburg army in May-June $1790 .{ }^{33}$ The victory at Yergöğü was one of a few Ottoman victories in the disastrous war of 1787-1792. The sultan conferred special grants to Cengiz Geray and his brothers in recognition of their bravery. ${ }^{34}$

30 For the âyân elections, see YAYCIOĞLU, Partners of the Empire, 117-155.

31 Sofroni Vrachanski, Avtobiografiia na Sofroni Vrachanski. Sofia: Bulgarska akademiia na naukitie, 1914, 85.

32 BOA, CA 29/1327.

33 BOA, CA 49/2255. Also see Ahmed CÂvid, Hadîka-i Vekâyi, Ankara: TTK 1998, 30-31; Ahmed Cevdet Paşa, Tarih-i Cevdet, vol. 3, Istanbul: Üçdal Neşriyat, 1984, 1195-1197.

34 İsmail Hakkı UzunçARşıLI, Osmanlı Tarihi, vol. IV, part I. Ankara: TTK, 1995, 568; Ahmet Cevdet Paşa, Tarih-i Cevdet: 1197, BOA, CA 1101/48629; BOA, CH 85/4201; CM 623/25644; BOA, CEM 17/824. 
War was an opportunity for warriors and entrepreneurs to prove themselves on the battlefield and acquire new missions and offices. But it was also an occasion for warriors from different regions of the empire to meet one another. In 1790, Cengiz Geray met Osman Pazvantoğlu, a provincial Janissary officer in the Ottoman army. ${ }^{35}$ Pazvantoğlu would soon be magnate of Vidin and one of the most powerful notables of Rumelia.

The competence of Cengiz Geray as a warrior demonstrates the martial culture into which the Gerays were born. Cengiz Geray's personal militia acted as a small military unit. While leaving the battlefield, Cengiz Geray's team took two of fortress's field cannons for their own use. The authorities immediately demanded the return of the cannons. This episode illustrates the extent of military expertise that a semi-private unit gathered under regional notables and the Gerays. The minor crisis between the authorities and Cengiz Geray did not prevent the Ottoman Court from asking him for another critical mission. He was soon commissioned, along with two other Ottoman commanders, to complete the delicate task of apprehending Nikolaos Mavrogiannis, the former Greek Hospodar of Wallachia, and confiscating his property. ${ }^{36}$ In April 1791, after receiving praise for his past services and valor, Cengiz Geray was authorized to gather "a couple of thousand warriors from the Deliorman/Ludogorie and other places" for the mission. ${ }^{37}$

\section{An Outlaw}

Despite his active participation in combat, Cengiz Geray was not detached from local politics. After all, none of his postings were far from his estate in Shumen. Rivalry for domination of this district between Cengiz Geray and his nemesis, the âyân of Shumen, Çavuşzade İsmail, was underway, even during the war. In January 1791, in his report to Istanbul, Cengiz Geray accused Çavuşzade of collecting unlawful taxes from peasants in the district. ${ }^{38}$ It seems that Cengiz Geray still enjoyed the backing of Ottoman authorities. However, Cengiz Geray's favorable relations with the central authority soured before long. When the Grand Vizier visited the area close to Vyrbitsa with the imperial army, local estate-holders and communities were asked to supply necessary provisions for his men, as was

35 Robert ZENs, "The Ayanlk and Pasvanoğlu Osman Paşa of Vidin in the Age of Ottoman Social Change, 1791-1815,” Unpublished PhD Dissertation, University of Wisconsin: Madison, 2004, 154. $36 B O A$, CEM $12 / 584$.

37 BOA, CA 67/3170; BOA, CA 169/7405.

38 BOA, CM 264/10832; BOA, CD 56/2762. 
common practice. Such demands were a significant burden for locals. Cengiz Geray felt uneasy with the demands of Ottoman dignitaries. According to the local version of the story related by a Bulgarian priest (later bishop), Sofroni of Vratsa, Cengiz Geray refused to submit to demands from the Ottoman Grand Vizier. His attitude against the Grand Vizier generated serious tensions. As Sofroni narrates, the Ottoman Grand Vizier had the estate of Cengiz Geray demolished, probably in his absence. ${ }^{39}$ Archival sources substantiate Sofroni's version. ${ }^{40}$ In coming years, Cengiz Geray justified his uprising with this disgrace committed by Ottoman authorities.

The Ottoman Court declared Cengiz Geray an outlaw on the grounds that he refused to collaborate with the Grand Vizier. In February 1792, Ottoman officeholders and local notables in Northern Bulgaria were asked to capture and send him to the island of Bozcaada/Thenedos for exile. ${ }^{41}$ Instead of facing capture, Cengiz Geray, along with his brother Bahadır and his men, headed for the countryside as fugitives. ${ }^{42}$ It was not a difficult task for Cengiz Geray to raise a sizeable force among the mountaineers, who were scattered across Rumelia after the war. Observers claimed that Cengiz Geray was able to raise 200 horsemen and 300 foot soldiers. ${ }^{43}$ Among his men was Tirsiniklioğlu İsmail, the future powerful magnate of Rusçuk/Ruse. ${ }^{44}$

In a short time, Cengiz Geray and his brother changed political dynamics in central Bulgaria. For some local competitors in Shumen, his departure provided new opportunities to fill the power vacuum left by the Gerays. Some notables in the region sent petitions to Istanbul, asking the state not to allow the Geray brothers to return to the district. ${ }^{45}$ But for many others, it was not easy to choose between a disappointed Chinghisid prince and desperate Ottoman authorities, since both Cengiz Geray and Ottoman authorities could punish them. ${ }^{46}$ When Cengiz Geray sought the collaboration of his fellow Gerays and some notable families, some refused to help, while others provisioned and sheltered him. ${ }^{47}$ The Ottomans tried to put pressure on local notables to prevent any collabora-

39 Sofroni Vrachanski, 111.

$40 B O A$, A.DVN.KRM (Dosya), 1/45.

41 BOA, CZ 27/1322; BOA, CH 37/1805.

42 HEZARFEN II, p. 319.

43 BOA, A.DVN.KRM (Dosya), 1/3.

44 Vera Moutaftchieva, L'anarchie dans les Balkans à la fin du XVIIIe siècle, Istanbul : ISIS, 2005, 64.

45 BOA, CH 93/4611; BOA, CD 116/5797; HeZARFEN II,. 319-320; BOA, A.DVN.KRM (Dosya), 1/45; BOA, CH 37/1811.

46 Moutaftchieva, 64.

47 BOA, A.DVN.KRM (Dosya), 1/3. 
tion with Cengiz Geray. Osman Ağa - a powerful figure in the region, the âyân of Tirnova, and Cengiz Geray's father-in-law- was executed under the accusation that he had sheltered Cengiz Geray. ${ }^{48}$

Following these measures, in late 1792, the brothers fled outside the Ottoman borders and took refuge in the Russian Empire. Cengiz Geray remained in Russian lands for six years. ${ }^{49}$ Upon his flight, products from his estates were confiscated and sold for the imperial treasury. Contemporaries noted that apart from harvested wheat and barley, Cengiz Geray had only eight oxen and eight weak draft horses. This confiscation was carried out under the supervision of Çavuşzade İsmail, his main antagonist. ${ }^{50}$ The rest of his properties were allocated to a variety of notables in the region..$^{51}$

\section{Refuge in Russia}

We do not know the details of the Geray brothers' journey from Ottoman Bulgaria to the Russian Empire. An Ottoman diplomat in Russia reported that he heard that the Geray brothers fled to Russia through Poland and went to Moscow. ${ }^{52}$ It was likely that Russian authorities knew of the Gerays' border crossings. It would not have been difficult for them to find necessary connections in Russian lands, including pro-Russian Crimean notables and merchant networks operating in the frontier areas of the two empires. Still, he must have received protection from Russian authorities before deciding to leave Ottoman lands. Cengiz Geray was reportedly granted an estate near Moscow..$^{53}$ Documents later illustrated that he not only settled in or around Moscow, but also had close connections to leading Russian dignitaries.

A report submitted by the Russian ambassador in Istanbul to the Russian administration suggests that during Cengiz Geray's stay of six years, he was protected by Potemkin, probably Pavel (the nephew of the renowned Grigoriy Aleksandrovich Potemkin). Pavel Potemkin was deeply involved in Caucasian and Polish affairs. He had also fought against the Ottomans in İsmail while Cengiz Geray was on the opposite side of the battlefield, making it possible that Pavel

48 Ahmet Cevdet Paşa, 1368; HeZarfen II, 320.

49 Sofroni Vrachanski, 111.

50 BOA, CH 33/1649.

51 ZENS, 155.

52 Hayreddin Nedim, Bir Elçinin Tarihçe-i Sefareti. Istanbul, 1333 [1917], 93.

53 Ibid. 
and Cengiz Geray knew of each other. Once his enemy, Pavel now hosted him in a courtly way and with due respect for his pedigree. Later, in Cengiz Geray's letter to the Russian Minister in Istanbul, he stated that he was well received at the Russian court, and granted valuable gifts, reference letters, and a Russian passport. ${ }^{54}$

Cengiz Geray did not bring his family, except for his brother Bahadir and perhaps close servants. ${ }^{55}$ Was he involved in Moscow's social life? A report, presented to Bonaparte in 1801, shows that Cengiz Geray's reputation in Paris was already growing. The report described Cengiz Geray as "brave, knowledgeable, humane, and not unfamiliar to the liberal thought which spread to Europe by the French Revolution.” The same report claimed that Cengiz Geray was educated at Catherine Il's court in Russia and had a personal relationship with her son, the Grand Duke Paul, who was to become Emperor in $1796 .^{56}$

While Cengiz Geray's familiarity with the ideas of the French Revolution may have been overstated, we do not have any reason to believe that he was isolated from Moscovite elites. Throughout the 18th and early 19th centuries, several individuals crossed borders, sought asylum, and developed connections between these two empires. A Chingisid prince and former Ottoman war hero against the Russian army, but now a fugitive, might attract particular attention from Moscovite elites, who slowly became acquainted with the conventions of Turkic and Muslim polities newly under Russian control. In fact, Russia was a regular destination for many refugees who fled from the Ottoman Empire in the late 18th and early 19th centuries. ${ }^{57}$ In addition to the refugees, Moscow habitually hosted highranked Ottoman captives, some of which spent many years as respected hostages in mansions granted to them around the city. It was clear that Cengiz Geray was considered a valuable asset, even for strategic reasons should a new war between the two empires break out.

In the first half of 1798, Cengiz Geray went to the Caucasus with his brother Bahadir as a guest of the Temirguey tribe of Circassians (Adiges). ${ }^{58}$ Nearby

54 Arkhiv Vneshnei Politiki Rossiskoi Imperii [Archive of the Foreign Policy of the Russian Empire] (AVPRI), Moscow, Fond 89, Snosheniya Rossiii s Turtsiei, op. 89/8, delo 924, I. 66.

55 BOA, Cevdet Dahiliye 59/2901.

56 Ivan Pavlovich, ed., Spomenik II. Ispisi iz frantsuskikh arkhiva, Belgrade, 1890, 124.

57 For similar cases that the Russian Empire accepted Muslim political refugees and émigrés from different pedigrees, see Michael Khodarkovsky, Russia's Steppe Frontier: The Making of a Colonial Empire, 1500-1800, Bloomington, IN: Indiana University Press, 2002, 202-210. For an account of Pehlivan İbrahim Paşa's stay in Moscow as captive in the early 19th century, see: Gazzizâde Abdullatif Efendi, Vekâyi'-i Baba Paşa fî̀t-târîh, edited by Salih Erol, Ankara: TTK Yayınları, 2013, 249-256.

58 The brothers' connections to the Circassian tribes continued during their stay in Moscow. Bahadır visited the region when the brothers lived in Moscow, and in 1793, nobles of the Adige 
Ottoman authorities sent an agent to the Temirguey tribe to inquire about Cengiz Geray's intentions in August 1798. Interviewed by the Ottoman official, Cengiz Geray explained that he had been desolated in Russia and intended to live in Muslim lands. He added that he had not heard from his family in Rumelia for years. Cengiz Geray had served the Ottoman Empire in the past and was ready to once again sacrifice his life for the empire. He mentioned that his flight to Russia was because of a conspiracy of his enemies in Rumelia who had vilified him to the state. To prove his case, he handled the Ottoman official a letter from Pazvantoğlu, endorsing his case..$^{59}$

\section{Back to the Ottoman Lands}

Consequently, Selim III pardoned Cengiz Geray in September $1798 .^{60}$ The Ottoman-Russian rapprochement against France, following the French invasion of Egypt, enabled the Russian authorities to lead Cengiz Geray to return to the Ottoman lands. Ottoman authorities ordered him to be discreetly put on a ship in Anapa, on the northern coast of the Black Sea, and sent directly to Istanbul. This amnesty, however, generated a heated debate in the Ottoman Divan. Dignitaries who were uncomfortable with Cengiz Geray's return proposed fabricating a conspiracy. According to this plan, Geray would at first be flattered with reiterations of his past services and offered a place in the army with an allowance. If he agreed, Cengiz Geray would be sent away to the army by sea. His refusal would serve as pretext to exile him to an Aegean island. Since this conspiracy would damage the state's trustworthiness, however, the acting Grand Vizier wrote in his report to Selim III that it would be prudent to settle Cengiz Geray in an estate around Vize (near Tekirdağ in present-day Turkey), where several members of the Geray dynasty had estates. Sahib Geray Khan II, the ex-Crimean Khan and then the representative of the dynasty, was informed about the decision. ${ }^{61}$

In the summer of 1799, Cengiz Geray sailed from Anapa to Istanbul. Upon arriving, he was hosted in the residence of an Ottoman officeholder, where he was asked to go to Rumelia and apply to Sahib Geray Khan II so that he could

tribes had asked the Ottoman Court for a pardon on behalf of Bahadır with a petition. $B O A, C D$ 47/2344.

59 BOA, CH 59/2901.

60 Ibid.

61 BOA, CH 26/1251; BOA, HAT 249/14129. 
find him a suitable estate. ${ }^{62}$ Instead of going to Vize, however, Cengiz Geray intended to go to Shumen and claim his own estate, which had been confiscated six years ago. Soon, he headed to Tirnova, a city where he had connections through his deceased father-in-law. Rumors reached Shumen that Cengiz Geray was returning with a local militia. The news alarmed his former rivals, the âyâns of Shumen and Hezargrad/Razgrad, who agreed to confront Cengiz Geray together. They even considered inviting Tirsiniklioğlu, once Cengiz Geray's loyal man and now the magnate of Ruse, an important city on the Danube, to join the coalition. ${ }^{63}$

\section{Rebellion}

In 1798, Osman Pazvantoğlu, the magnate of Vidin, was declared an outlaw. A sizable Ottoman army unsuccessfully besieged Vidin for three months. Pazvantoğlu had risen from a petty local Janissary to a regional powerholder. In the beginning, Pazvantoğlu's aim was simply to be recognized by the Sultan as the governor of Vidin. Gradually, however, he colored his challenge with anti-New Order rhetoric. The New Order (Nizâm-ı Cedîd), initiated by Selim III and a group of reformists in Istanbul, was the name of a military and fiscal reform movement and, at the same time, the name of the new trained army, assembled as an alternative to the Janissary corps. When rumors spread that Selim's real intention was to replace the ancient Janissary corps with a new army, Pazvantoğlu gained popularity among the provincial Janissaries. He also became popular with various communities that denounced the New Order because of the extra taxes required to finance the reforms. ${ }^{64}$

To the east, another magnate, Tirsiniklioğlu İsmail Ağa established power in Rusçuk/Ruse. By 1799, Tirsiniklioğlu had gathered considerable financial power, recruiting militias from the region. It did not take long for him to establish good relations with the New Order party in Istanbul as a tax collector for the new treasury. ${ }^{65}$ In 1799, while these two magnates dominated Danubian Bulgaria, Cengiz

\section{Ibid.}

63 Lamenting the fact that Cengiz Geray was missed, on the report of the acting Grand Vizier (Kaymakam) Selim III wrote: "This is what happens when the [necessary] measure is not taken when he was at hand.” BOA, HAT 249/14129.

64 Tolga Esmer, "Economies of Violence, Banditry and Governance in the Ottoman Empire Around 1800," Past and Present 224 (2014): 163-199.

65 YAYCIOĞLU, Partners of the Empire: 92-95. 
Geray came back to the region. His meetings with members of the Geray family and some brigand leaders alarmed Ottoman authorities. ${ }^{66}$ As representative of the central authority, Köse Musa Pasha, the governor of Silistra, was in charge of capturing Cengiz Geray. Lacking sufficient troops, however, Musa had to handle the delicate business of bringing together local notables, including Tirsiniklioğlu, against Cengiz Geray. In fact, Musa Pasha was informed that Tirsiniklioğlu had invited Cengiz Geray, his former master, to Ruse, and that the two men had agreed to cooperate. ${ }^{67}$ We do not know whether this meeting took place. In fact, a possible alliance between Cengiz Geray and rebellious Pazvantoğlu was more threatening for Ottoman authorities. Cengiz Geray would provide Pazvantoğlu with access to central Bulgaria, approaching Razgrad, Tirnova, and Shumen. ${ }^{68}$ In early March 1800, a decree was issued to the âyâns of these regions to act in alliance under the command of Musa Pasha to capture Cengiz Geray. ${ }^{69}$ When the news spread out that Cengiz Geray and Pazvantoğlu established an alliance, Tirsiniklioğlu decided to collaborate with Musa. ${ }^{70}$

At that moment, Cengiz Geray established himself in the town of Eskicuma with a force of 5,000-6,000 men, mainly Muslim and Christian mercenaries. ${ }^{71}$ Musa finally managed to gather troops from local notables, with Tirsiniklioğlu's help, and compelled Cengiz Geray to withdraw. ${ }^{72}$ Tirsiniklioğlu's participation in punitive actions against Cengiz Geray made Istanbul particularly happy. ${ }^{73}$

In the spring of 1800, several of Pazvantoğlu's men joined Cengiz Geray and began raiding towns on the Danube, in Wallachia, central Bulgaria, and eastern Thrace, where they approached vicinities of Istanbul. ${ }^{74}$ After bitter fighting between the forces of Cengiz Geray and Ottoman troops, Cengiz Geray was reportedly killed by a bullet. ${ }^{75}$ Soon, however, the news broke that the man killed was not Cengiz Geray, but his son, Devlet Geray. ${ }^{76}$ Ottoman authorities captured the village where Devlet Geray was killed and buried, and exhumed the corpse. Later, the young Devlet's corpse was beheaded, his head dispatched to Istanbul with others from killed or executed brigands. This unusually gruesome action was

66 BOA, HAT 46/2259; CZ 4117; CD 282/14058.

$67 B O A, C D 15 / 722 ; B O A, C D$ 285/14236.

68 BOA, НАТ 271/15802.

69 BOA, CD 286/14277.

70 BOA, HAT 258/14825.

71 Sofroni Vrachanski: 111.

$72 B O A, C D 34 / 1674$.

73 BOA, CZ 81/4032. BOA, CD 34/1674; CD 285/14236; CD 303/15124; CD 8/365.

74 BOA, CD 25/1248; BOA, HAT 68/2909A, 2813A; HAT 65/1231; BOA, HAT 72/3027.

75 BOA, HAT 64/2795A; HAT 67/2900.

76 BOA, HAT 65/2831. 
also a desecration of an old code of honor between the Ottomans and the Gerays, according to which no blood of a Geray should be spilled, even if he was to be executed.

\section{An Alliance and the Global Game}

In the early fall of 1800, Cengiz Geray met with Pazvantoğlu in Vidin. ${ }^{77}$ Ottoman forces attempted to cut supplies to Vidin from Wallachia, which was looted by Pazvantoğlu's men. ${ }^{78}$ This would prompt him and Cengiz Geray to act more closely. One contemporary observer even attributed the third revolt to Pazvantoğlu's devotion to Cengiz Geray. ${ }^{79}$

Meanwhile Russia, France, and Austria closely monitored developments in the Balkans. The Ottoman-Russian alliance against France following the French expedition to Egypt in 1798 provided the Russians with a pretext to send several agents to the Balkans. ${ }^{80}$ It was at this juncture that Pazvantoğlu initiated diplomatic efforts to obtain support from Russia and later France. He sent envoys, mainly Greek and Serbian merchants, to Moscow, Petersburg, and Paris. Pazvantoğlu also took advantage of his alliance with Cengiz Geray, whose name was now acknowledged in the courtly circles of Europe after his sojourn in Moscow.

Pazvantoğlu's contacts with Russia began sometime in 1800, possibly after Cengiz Geray's arrival in Vidin. He wrote a letter directly addressed to Emperor Paul, openly asking for Russian protection. Pazvantoğlu delivered the letter through Vasilii Stepanovich Tomara, the Russian Minister in Istanbul. Pazvantoğlu received a reply two years later, not from Paul, who had been assassinated in 1801, but his successor and son Alexander I. ${ }^{81}$ Meanwhile, he communicated with Russian diplomats in Wallachia. In his letter to Luka Kiriko, the Consul of Russia at Bucharest, Pazvantoğlu presented himself as the protector of the people of Wallachia and refused the allegations that his men were harassing Wallachian villagers. On the contrary, he claimed, his militia protected the peasant communities against brigands, and he was upset that the Hospodars, governors of Wallachia, who were appointed by the Ottoman state from Greek families in Istanbul,

77 Spomenik II, Ispisi iz frantsuskikh arkhiva,124.

78 Stoian NovaKovich, Tursko tsarstvo pred srpski ustanak 1780-1804, Belgrade, 1906, 377.

79 Spomenik II, Ispisi iz frantsuskikh arkhiva, 121.

80 SHAw, 305.

81 Pavel N. OReshrov, "Neskolko dokumenta za Pazvantoglu i Sofroniia Vrachanski (1800-1812)," Sbornik na Bylgarskata Akademiia na Naukite, Book 3. Sofia, 1914, 37. 
had cut his supplies. ${ }^{82}$ While Pazvantoğlu looked to build relations with Russian authorities, Cengiz Geray and the Bishop of Vidin, Kalinik, lobbied for him by sending letters to Russian officers defending Pazvantoğlu's case. ${ }^{83}$

Pazvantoğlu's contact with Russian authorities did not prevent him from negotiating a compromise with the Ottoman state. In January 1801, he sent his personal physician, Lampbo Canoğlu, to the Vice-Consul of the Russian Empire in Bucharest. Canoğlu conveyed Pazvantoğlu's request for assistance to win the goodwill of the Ottoman Court. Pazvantoğlu declared that if pardoned, he would be ready to contend with a much smaller army, and he would avoid intervening in Wallachia. ${ }^{84}$ In April 1801, Pazvantoğlu formally appealed to the Ottoman Sultan to pardon him and Cengiz Geray. He also explained the unfortunate situation of Cengiz Geray. In his letter, Pazvantoğlu wrote that the Sultan had allowed Cengiz Geray to reside in Vyrbitsa. However, mischievous figures in the region had conspired to prevent this, by denigrating him to the Sultan. ${ }^{85}$ After Pazvantoğlu penned this petition, on April 1801, one of Pazvantoğlu's military chiefs met Ottoman authorities in Craiova (Wallachia). Pazvantoğlu requested that they convey his wish that the Ottoman Court would pardon him and Cengiz Geray. When the request reached Istanbul, Selim III refused to confer amnesty to either one. ${ }^{86}$

Negotiations between Pazvantoğlu-Cengiz Geray, the Russians, and the Ottoman center illustrate the nature of contemporary regional and inter-imperial politics. While loyalties and alliances constantly shifted in a volatile environment, Pazvantoğlu requested mediation from a foreign power, Russia, in his negotiations with Ottoman authorities. Russia had increasing influence in the Porte and over the Greek governors of Wallachia and Moldavia. In this diplomatic maneuver, Pazvantoğlu must have thought that Cengiz Geray's connections with Russia and the bishop of Vidin's possible ties with Orthodox clerics in Russia and Istanbul would serve his case. Unsuccessful attempts by Pazvantoğlu and Cengiz Geray to close a deal with the Ottoman state through Russian mediation pushed the pair to consider an alternate plan. In the fall of 1801, two men, one from Vidin, another from Vienna, arrived in Paris, met with Charles Maurice de Talleyrand, the Foreign Minister, and delivered a letter from Pazvantoğlu. The two men were

82 Ibid, 33-34. For the major Greek families ruling Ottoman Wallachia and Moldavia, see Christine M. PHILliou, Biography of an Empire: Governing Ottomans in the Age of Revolution. Berkeley, CA: University of California Press, 2011.

83 OreshKov, 34.

84 Ibid, 35.

$85 B O A$, HAT 72/3017A.

86 BOA, HAT, nos. 72/3017 and 72/3017B. 
Nedel'ko Popovich, Pazvantoğlu's confident associate and chief of commercial and foreign affairs, and Polisoi-Condon, a Greek professor of Greek and Latin in Vienna. ${ }^{87}$ Greek residents of Austria had been in contact with Pazvantoğlu for a while, and Polisoi-Condon was a leader in Vienna's Greek community, which was involved in the affairs of the Ottoman Balkans and Greece. ${ }^{88}$

Pazvantoğlu's proposals to France had four main points. First, he proposed to assist the French government in a partition plan for the Ottoman Empire. Second, if the Republic of France attacked the Ottoman Empire, Pazvantoğlu promised to cooperate on the condition that the French government offered him and Cengiz Geray a province to rule in peace under the protection of France. Third, in case the French government chose to preserve the Ottoman Empire as it was, Pazvantoğlu pledged to cease hostilities against the Ottoman Court. In turn, the French government would request a pardon for him from the Ottoman State. Fourth, Pazvantoğlu gave his word to be faithful to the French Republic and serve its aims, provided they did not conflict with the principles of Islam. ${ }^{89}$ The ambitious proposals of Pazvantoğlu and Cengiz Geray to the French Republic demonstrate not only the range of radical options on the table for restructuring the political landscape, but also the imaginations of political actors from various backgrounds who participated in this global game. A new network that crossed imperial boundaries and connected a professor of Greek and Latin in Vienna with a rebel magnate in the Ottoman Balkans and a Chingisid prince who drifted between the Ottoman and Russian Empires reached all the way to Napoleon. In the age of revolutions, when major changes happened and were expected, Pazvantoğlu and Cengiz Geray insinuated that they were eager to play roles in this process under the leadership of revolutionary France. But when Napoleon Bonaparte received the letter, he was about to make peace with the Ottoman Empire. So he ignored the ambitious proposal from the two men.

Disappointed by the French Republic, Pazvantoğlu and Cengiz Geray again turned to the Russian Empire. In January 1802, Pazvantoğlu received a personal reply from Alexander I to the letter he sent to Alexander's father, Paul, two years before. The Emperor of Russia gave him "hopes of protection and friendly greetings” through the Russian Consulate General in Iaşi/Jassy. Pazvantoğlu quickly

87 Spomenik II, Ispisi iz frantsuskikh arkhiva, 123. Although Nedel'ko Popovich is cited in the sources as a Greek, his name suggests that he was a Christian Balkan Slav, most probably a Serbian. He was also a Russian subject. See OREshKov, 34.

88 Rossitsa Gradeva, “Osman Pazvantoglu of Vidin: Between Old and New,” Interdisciplinary Journal of Middle Eastern Studies, vol. 8 (2005), Special Issue: The Ottoman Balkans, 1750-1830: 137-138.

89 Spomenik II, Ispisi iz frantsuskikh arkhiva, 121-122. 
sent a note of reply, while carefully adding the seal of Cengiz Geray. The letter stated the two men's faith in the Russian Empire and asked for its protection against the Ottoman Empire. Consequently, in May 1802, Tomara, the Russian Minister to Constantinople, officially requested Pazvantoğlu's pardon from the Ottoman Divan. ${ }^{90}$

Pazvantoğlu also kept in contact with Arkadii Ivanovich Morkov, the Russian Minister in Paris. In all of his correspondence, Pazvantoğlu stated his wish to be under the protection of the Tsar. ${ }^{91}$ He wrote a flattering personal letter to Alexander I in June 1802. As usual, a note from Bishop Kalinik accompanied the letter, in this case, to Count Viktor Pavlovich Kochubey, who was in charge of the Collegia for Foreign Affairs. Having explained Pazvantoğlu's deep loyalty to the Russian Empire, the bishop stated Pazvantoğlu's intention to stand against the Ottoman Empire with the help of Russia. Under present circumstances, however, Pazvantoğlu was content with obtaining a pardon from the Sultan through the mediation of Russia. ${ }^{92}$ In July 1802, Tomara wrote to the Tsar that having acceded to Russian requests to pardon Pazvantoğlu, the Ottoman court demanded that he write a petition to Istanbul. Pazvantoğlu accepted this request, but remained unwilling to withdraw his militia from Wallachia. ${ }^{93}$

Meanwhile, although Pazvantoğlu was working with the Russians, suspicions arose that he was serving French interests. ${ }^{94}$ The presence of Pazvantoğlu's envoys in Paris caused discomfort. While maintaining contact with the Russian Minister in Paris, the Russian side believed Pazvantoğlu's men were there to conduct negotiations with the French. ${ }^{95}$ These diplomatic tactics directed at multiple powers at the same time created rumors, not surprisingly, accusing Pazvantoğlu and Cengiz Geray of being French, Austrian, or Russian agents. ${ }^{96}$

Around the same time, a report to Napoleon Bonaparte claimed that in accordance with the agreement between Cengiz Geray and Pazvantoğlu, the two men would march on Istanbul. The Geray would sit on the throne, while Pazvantoğlu became Grand Vizier. ${ }^{97}$ Records show that during a conversation with Arkadii Ivanovich Morkov, the Russian envoy to Paris, on August 4, 1802, Napoleon Bon-

90 ORESHKOV, 37-39.

91 Ibid, 37.

92 Ibid, 39.

93 Vneshniaia politika Rossii. XIX i nachala XX veka, First Series, vol. 1. Moscow, 1960, 246.

94 Ibid, 314.

95 Ibid, 318.

96 Deena R. SAdat, Urban Notables in the Ottoman Empire: The Ayan, Unpublished PhD Dissertation, Rutgers University: New Brunswick, NJ, 1969, 131-132.

97 Spomenik I,. Ispisi iz frantsuskikh arkhiva, 124. 
aparte half-jokingly uttered the possibility of a Chinghisid prince in Russia being placed on the Ottoman throne if necessary. ${ }^{98}$ Although we cannot determine how serious this inkling was, when Vasilii Tomara, the Russian Minister in Istanbul, informed the Ottomans of the First Consul's statement, it generated distress in Istanbul. ${ }^{99}$ Undoubtedly, Napoleon had Pazvantoğlu and Cengiz Geray in mind.

There is no evidence of the validity of the report, submitted to Napoleon, on the plot of Pazvantoğlu and Cengiz Geray to raid Istanbul and dethrone the Sultan. What is evident is that Pazvantoğlu's diplomatic effort to receive a pardon from the Ottoman state through Russian mediation was successful. Selim III granted amnesty to Pazvantoğlu and restored his title of Vizier in August 1802. ${ }^{100}$ Soon, Pazvantoğlu's request for amnesty for Cengiz Geray was also accepted by the Ottoman state. Pazvantoğlu was successful not only in receiving amnesty, but also in pushing the Ottoman court to recognize his authority in Vidin and the surrounding region through diplomatic maneuvers. It was clear that the Pazvantoğlu-Cengiz Geray alliance worked in Pazvantoğlu's favor. For the Ottomans, such an alliance, which garnered inter-imperial attention, created a serious threat. The amnesty granted to Pazvantoğlu and Cengiz Geray testified to the Ottoman state's inability to eliminate these players. At least amnesty could prevent them from collaborating with the French or Russian interests as a result of their desperation in a hostile environment.

If Pazvantoğlu and Cengiz Geray had ever imagined such a grandiose project as carving a monarchy from the Ottoman Empire to jointly preside over under the protectorate of France or Russia, they failed to realize it. Neither France nor Russia considered their proposition a viable option. Nevertheless, the radical proposal by Pazvantoğlu and Cengiz Geray circulated not only in diplomatic circles, but also among ordinary people in the Balkans. Sofroni of Vratsa, the Bulgarian bishop who was in the area during the challenge of Cengiz Geray and Pazvantoğlu, wrote in his memoirs:

There was a [Geray Sultan] living in Vyrbitsa who had defeated the Germans [Austrians] in Giurgiu. Because of his pride, he refused to be obedient to the vizier who encamped in Şumnu with his army. The vizier ordered the demolition of the estates of the Geray. Then, the Geray fled to the Muscovites. He stayed there for six years. Then he went to Istanbul with the mediation of the Muscovites. The [Ottoman] Sultan told him that he could rebuild his estates. On his way to Vyrbitsa, he collected an army constituted by Turks and Christians

98 Aleksandr Trachevskii, ed., Diplomaticheskie snosheniia Rossii s Frantsiei v epokhu Napoleona I, vol. I, St. Petersburg, 1890, 485.

99 Anatolii Filippovich Miller, Mustafa Pasha Bairaktar, Moscow: Izdatel’stvo Akademii Nauk SSSR, 1947, 574.

100 Ahmet Cevdet Paşa, Tarih-i Cevdet, vol. 4, 1831. 
and went to Vidin. I do not know what the Geray discussed with Pazvantoğlu, but according to the rumors, they agreed to make Cengiz Geray the sultan and Pazvantoğlu the vizier. ${ }^{101}$

\section{Separation and Death}

Following his pardon, Pazvantoğlu requested amnesty from the Porte for Cengiz Geray. He had also asked the authorities to allow residing in Saray in eastern Thrace. Both requests were finally granted, although since Cengiz Geray's behavior was deemed unpredictable, he was asked to go to Bursa, far from Rumelia. ${ }^{102}$ There were signs of Pazvantoğlu's relationship with Cengiz Geray souring. Cengiz Geray's prolonged presence in Vidin became a burden for Pazvantoğlu. In a document from the second half of 1802, an Ottoman official (sympathizing with Pazvantoğlu) reported from Vidin that the sojourn of Cengiz Geray, along with his entourage, was burdensome. No doubt reflecting Pazvantoğlu's opinion, the official stated that while Pazvantoğlu (now "Osman Pasha and the Commander of Vidin") had hosted Cengiz Geray, "lest he did not join the brigands," it would be appropriate to bestow his former salary and grant him residence on his estate in Saray. ${ }^{103}$

In January 1803, Cengiz Geray died in Vidin. Writing to the Ottoman Court and mentioning Geray with respect, Pazvantoğlu still used the phrase "thank God, [with his death] we have been redeemed of his tribulation." 104 The death of this exceptional Geray in Rumelia took place just when he was just pardoned and about to leave his enforced sojourn in Vidin. Osman Pazvantoğlu would die four years later.

\section{Bahadır Geray}

After the death of Cengiz Geray, his brothers were entitled to a monthly allowance and land, though this seems to have been suspended due to their participation in the affairs of Cengiz Geray. On March 13, 1803, Pazvantoğlu wrote to the Porte requesting the restoration of Bahadir's income. ${ }^{105}$ Six days later, Sahib

101 Sofroni Vrachanski, 111.

102 BOA, HAT 107/4211.

103 BOA, HAT 71/2989A.

104 BOA, HAT 107/4211.

$105 B O A$, CH 58/2859. 
Geray Khan II, the ex-Crimean Khan and Representative of the Geray dynasty in the Ottoman Empire, also wrote in support of this request. ${ }^{106}$ Bahadir was finally granted an annuity of 1,500 guruş. ${ }^{107}$ In April 1803, an imperial decree allowed Bahadir to reside on the estate of his grandfather in Saray. ${ }^{108}$ The Sultan granted him an imperial gift of 1,000 guruş in May 1803. ${ }^{109}$ Bahadır was also granted a new estate in Saray of Vize. ${ }^{110}$ For some reason, he never received the estate, prompting Bahadir to ask for the former estate of his late brothers Cengiz Mehmed Geray and İslam Geray in the district of Şumnu. As of 1807, Bahadır was still with little income and without his estate. ${ }^{111}$

In the meantime, Bahadır Geray stood out as a heroic warrior during the Ottoman-Russian war of 1806-1812. Since he performed remarkably in battles around İsmail, in February 1807, he was awarded the title and post of qalgay of Bucak. ${ }^{112}$ This was the resurrection of a title and post of the Crimean Khanate, almost a quarter of a century after its demise. As special units were organized exclusively from the Tatars in the Ottoman Empire, their command was given over to Bahadir with the title of qalgay and the "Tatar Commander", i. e., the commander of Tatar troops. ${ }^{113}$ But by the end of the war, Bahadir was taken prisoner by the Russians. ${ }^{114}$ In subsequent years, Bahadır continued to live on the estate of Cengiz Geray in the village of Vyrbitsa. His direct descendants continued to live in this village until the 1970s. ${ }^{115}$

\section{Chingissid Charisma in the Napoleonic Age}

The Gerays and the Ottomans launched their dynasties in the same context, more or less, following the disintegration of Mongol Eurasia in the 14th and 15th centuries. The Gerays, as heirs of Chingis Khan, claimed the legitimate succession of

\footnotetext{
106 Ibid.

107 Ibid.

108 BOA, MÜнImme 220, 66, sentences 241 and 248.

109 BOA, CH 133/6634.

$110 B O A$, CH 50/2485.

$111 B O A, \mathrm{CH} 48 / 2384$.

112 BOA, CH 130/5134; Ahmed Âsım, Tarih-i Âsım, vol. 1, Istanbul, 1267 [1850-1851], 216.

113 BOA, CH 130/5134; Şânî-zâde Mehmed Atâ’ullah Efendi, Şânî-zâde Târihi (Ziya Yılmazer, ed.), vol. I, Istanbul: Çamlıca, 2008 107; vol. II, 1150.

114 BOA, CH 100/4978.

115 İsmet GIRAY, “Atalarım Gerayların Bulgaristan’daki Sarayı ve Bazı Hatıralarım,” Emel (Ankara) 209 (July-August 1995): 18-20.
} 
the Golden Horde Empire and declared their khanate in Crimea. The Ottomans, who were initially humble warriors, operating in the frontier zone of Anatolia between the Islamic world and Eastern Rome, did not have such a majestic claim. In the 15th century, however, when the Ottomans established one of the largest and most ambitious political enterprises of the early modern era, with new imperial claims to the Islamic world and Eastern Europe, the Gerays were pushed to accept the suzerainty of the Ottoman sultans.

Following the incorporation of Crimea into the Ottoman Empire, the Gerays became part of the Ottoman imperial establishment with their distinctive Chinghisid pedigree, which was recognized and respected by Ottoman elite and the public. Members of the Geray dynasty, while ruling Crimea for centuries under the Ottoman imperial umbrella, played important roles. Sometimes, the Gerays acted as loyal members of the Ottoman imperial establishment, or, as unruly nobles with their own vision of political geography, power, and nobility, and occasionally, they challenged the conventions of the Ottoman central state. While the Geray pedigree, from their Chingisid ancestry, continued to furnish them with distinctive status in the empire, the family was, albeit tacitly, considered the second most prestigious house that could replace the Ottoman family if the Ottoman lineage terminated. Oppositional groups sometimes voiced the possibility of replacing the Ottomans with the Gerays in times of crisis. When the Russian Empire annexed Crimea in 1783, the Gerays left Crimea for the Balkans, becoming a "dynasty in exile," and gradually made the Balkans, where most of the family already had estates granted by the Ottoman sultans, their homeland.

Cengiz Geray was one of the Gerays settled in the Balkans. Starting his life as a promising prince, Cengiz Geray was forced to leave Crimea and begin a new life in the Balkans. The late 18th century was a period of crisis for the Ottoman order. While Ottoman central authority was dramatically dismantled in the provinces, several families and individuals, who were not connected to the imperial elite but came from modest backgrounds, consolidated unprecedented power and accumulated wealth in their respective regions, challenging and changing the established regime.

Meanwhile, the Ottoman Empire was shaken by the Ottoman-Russian wars and the French expedition to Egypt. In addition, revolutionary storms in Europe gave birth to new partition plans, dynastic shifts, and regime changes on a global scale. ${ }^{116}$ Under these dramatic circumstances, several individuals and families

116 We have to note that European projects to capture Istanbul or Jerusalem and partition the Ottoman Empire were not unique to the Napoleonic period. Since the 15th century, in various moments, such plans were put forward by political and religious authorities in France in a messi- 
found new opportunities to play roles beyond the conventional limits of the Ottoman Empire. Ali Pasha of Yanya/Ioannina, according to European circles, exploited possibilities to establish a separate kingdom under his and his sons' rule. Theodore Lascaris, a Maltese knight who was linked to the Byzantine imperial family, the Lascaris, together with Ya'qup Hanna, the Coptic general from Egypt who collaborated with the French during the expedition, proposed to the British and French governments to create an independent Egypt under the rule of Murad Bey, a Mamluk oligarch in Egypt. ${ }^{117}$ While such separatist projects were discussed in different circles, the Gerays, who were scattered in the Balkans, offered new possibilities with social and political capital derived from, as Devin DeWeese puts it, the Chinghisid charisma. ${ }^{118}$

Pazvantoğlu, an energetic provincial magnate, and Cengiz Geray, a disappointed Chingisid noble known in Europe's high circles as a result of his long sojourn in Russia, seemed to sense this trans-imperial opportunity. They united powers and attempted to play a role in the revolutionary period between 1798 and 1802. Pazvantoğlu and Cengiz Geray presented themselves as an ally to France and Russia who could help re-design the Ottoman world. The partnership of Cengiz Geray and Pazvantoğlu was not the only one. Ali Pasha of Ioannina, who controlled Ottoman Albania and Greece, was also rumored to have taken part in a conspiracy to replace the Sultan with a certain Ali Geray. ${ }^{119}$ Claims of a similar enterprise by Mustafa Bayraktar, who replaced Tirsiniklioğlu İsmail in 1806, following his murder, also existed. Later, in 1808, Mustafa Bayraktar initiated a coup in Istanbul, in alliance with a faction of the central government, and dethroned Mustafa IV, enthroned Mahmud II, and imposed himself as Grand Vizier. ${ }^{120}$

anic tone, aiming to establish Christian rule in the Holy Land of early Christianity: see Alexandre Y. HARAN, Le lys et le globe: messianisme dynastique et rêve impérial en France à l'aube des temps modernes, Seyssel, 2000, 269-309; Faruk BILICI, Louis XIV et son projet de conquête d'Istanbul, Ankara, 2004. In the 18th century, partition plans of the Polish Republic and the Ottoman Empire were presented in Europe as enlightened projects to end the corrupt or despotic regimes. For Catherine the Great project to carve an enlightened Neo-Byzantine State in Istanbul and around: see Hugh Ragsdale, "Evaluating the Traditions of Russian Aggression: Catherine II and the Greek Project,” The Slavonic and East European Review, vol. 66, no. 1 (1988): 91-117.

117 George A. HADDAD, “A Project for the Independence of Egypt, 1801,” Journal of the American Oriental Society, vol. 90, no. 2 (1970): 169-183.

118 Devin Deweese, Fusing Islam and Chinggisid Charisma: Muhammad Shïbãnî Khãn's Religious Program in 16th-century Central Asia, unpublished paper presented at Stanford University, October 11, 2011.

119 Grigorii L'vovich ARsh, Albaniia i Epir v kontse XVIII-nachale XIX v.: zapadnobalkanskie pashalyki Osmanskoi imperii, Moscow, 1963, 229.

120 YAYCIOĞLU, Partners of the Empire, 157-201. 
Observers noted that after the coup, Mustafa Bayraktar considered replacing Mahmud II with Selim Geray, son of Kaplan Geray Khan II and a very influential figure, whom he was keeping (or hosting) in his court with whom he was in closed contact. ${ }^{121}$ Clearly, between the late 18th and early 19th centuries, crisis, instability, and uncertainty prevailed. But so too did new possibilities, unprecedented opportunities, and turning points. The old Geray option and their Chingisid charisma in the Ottoman world, heightened by the ambitions of new political entrepreneurs like Pazvantoğlu of Vidin, Ali of Ioannina, and Mustafa Bayraktar, gave birth to a new coalition of old and new, pedigree and provincial notables, social capital and military/financial power.

Did Chinghisid charisma provide important capital beyond the Ottoman world? Chinghisid ancestry continued to serve as a major reference for legitimacy claims for competing dynasties throughout Islamic Eurasia in the early modern period. Just like the Ottoman Empire, in Islamic Central Asia and Mughal India, the Chinghisid genealogy was resurrected in various ways, on different occasions in the early modern period. ${ }^{122}$ The Chinghisid legacy was also known in Western Europe and Russia. In British, French, and Austrian literary and academic circles, the growing literature on the Islamic world and China in the 17th and 18th centuries, the rise of Chinghis Khan, and the expansion of the Mongol empire from China to Europe were central issues in Orientalist literature. ${ }^{123}$ The Latin translation of Tarikh-i Mukhtasar al-Duwal, the history of the renowned Syriac historian of the Mongol era, Bar Hebraeus (Abu'l-Faraj), by Edward Pococke in 1663, provided Gibbon and other historians of the Enlightenment with a fresh perspective on the rise of the Mongol Empire and the claims of Chinghisid nobilities spread across Eurasia. $^{124}$

In Russia, memories of the Mongol and Chinghisid claims were much livelier than in Western Europe, since the Muscovite state had long been under the suzerainty of the Golden Horde Empire and its successors. After the consolidation of the Russian Empire following the collapse of the alliance of the Crimean and Kazan Khanates in the mid-16th century, Russia incorporated the Chinghisid

121 Antoine De Juchereau de Saint-Denys, Révolutions de Constantinople en 1807 et 1808, vol. 2, Paris, 1819, 212. Selim Geray, who was the son Kaplan Geray Khan II, was then residing in his mansion in the village of Subaşı near Çatalca.

122 Robert D. McChesney, "The Chinggisid Restoration in Central Asia: 1500-1785," in The Cambridge History of Inner Asia: The Chinggisid Age: 277-301; DeWeEse, "Fusing Islam and Chinggisid Charisma".

123 J. G. A. Pососк, Barbarism and Religion, vol. 4, Barbarians, Savages and Empires. Cambridge: Cambridge University Press, 2005, 107, 101, 134.

124 Historia Compendiosa Dynastarum, Oxoniae, Davis, 1663. 
dynasty of Kazan and began expanding towards Central Asia. This process pushed Russian imperial elites to develop profound expertise on Chinghisid elements in Muslim Central Asia. ${ }^{125}$ The conversion of a number of members of the Volga Tatar aristocracy from Islam to Orthodox Christianity and their incorporation into the Russian nobility is yet to be studied in depth. Nevertheless, the Russian imperial elite's fascination with noble ancestries turned the Chinghisid and other notable Tatar lineages into principal references within the Russian imperial context. When Antioch Kantemir, a Russian nobleman, diplomat, and an active voice in the Republic of Letters in the age of Enlightenment, was disparaged by Voltaire for having Greek origins, he proudly maintained that his ancestors were not Greek, as Voltaire argued, but Timurid. In fact, his name Kantemir ("Khan Temir"), Antioch claims, had referred to Timur or Tamerlane, the great empirebuilder in Central Asia and Iran who claimed to revive the Chinghisid Empire in the 15 th century. ${ }^{126}$

Catherine II's annexation of Crimea in 1783 and Napoleon's expedition to Egypt in 1798 opened a new page in the history of Western knowledge of the Islamic world. Catherine's project to coopt Crimean nobles, who did not emigrate from Crimea to the Ottoman lands, and reshape them in accordance with the new imperial configuration, triggered vibrant discussions about legitimate ancestries among Crimean nobles. Owing to Catherine's policy to integrate Muslim notables from acquired territories into the Russian Empire, imperial circles developed profound familiarity with the lineages, tribal affiliations, religious networks, and political culture of the Muslims of the Russian Empire. ${ }^{127}$ In this body of knowledge, or Russian Orientalism, the house of Chinghis elicited particular interest in Russian imperial circles. ${ }^{128}$ The noble status of the several Gerays who had settled in the Caucasus was recognized, by conferring titles of nobility equivalent to that of a prince. One Russian noble from Tavrida, in today's Ukraine, reported to Catherine II, discussing the strategic importance of Crimean notables, the Mirzas, who were being integrated into the Russian imperial system:

125 David Schimmelpenninck van Der Oye, Russian Orientalism: Asia in the Russian Mind from Peter the Great to the Emigration. New Haven: Yale University Press, 2010, 12-43.

126 His father Dimitri Kantemir, a Wallachian prince, who spent his youth in the Ottoman court, was the author of the famous history of the Ottoman Empire. Later Dimitri immigrated to Russia and became a member of the Russian academy of science. His book was translated into English under the supervision of his son Antioch and had a major impact in Western Europe on the discussions on the Ottoman Empire.

127 Kelly O'NEILL, "Rethinking Elite Integration: The Crimean Murzas and the Evolution of Russian Nobility,” Cahiers du Monde russe 51/2-3 (2010): 397-418.

128 SCHIMMELPENNINCK VAN DER OYE, 99-100. 


\begin{abstract}
[We must] train them imperceptibly in our customs, our amusements, the pleasure we take in our lives, and even in our work. This is all the more important because among the mirzas there are those who descended from Chinghis Khan, and Your Excellency well knows in what high regard and with what level of respect they are therefore held by the Muslim people. Whether they are indigent or legitimate heirs is immaterial - it is enough that the crowd believe them. Their devotion to Russia, their acclimation to our way of life secured, they might in future prove useful in political, military, and trade relations with Turkey. ${ }^{129}$
\end{abstract}

While Cengiz Geray was venerated for seven years in Russia in this atmosphere, Napoleon's expedition to Egypt, in contrast, prompted new engagements by French circles with the Ottoman Middle East and the Balkans. Partition plans for the Ottoman Empire coincided with shifting coalitions among the French, Russian, and Ottoman empires in the stormy conditions of the Napoleonic era. During this time, Juchereau DE SAINT-Denys, a French émigré and military advisor to the Ottoman Sultan, Selim III, wrote Révolutions de Constantinople, analyzing turbulent events that transpired between 1806 and 1808. JUCHEREAU not only compared the reformist Sultan Selim III with Peter the Great, but also emphasized the Tatar or Mongol roots of the Ottoman regime, rather than stressing its Islamic origins, a common approach among historians of the Ottoman Empire. ${ }^{130}$

While the fate of the Ottoman Empire was at stake in the radical transformations of the revolutionary and Napoleonic age, Chinghisid ancestry again served as diplomatic capital. Cengiz Mehmed Geray was a possible candidate in this game. A direct descendent of the Chinghisid Geray dynasty, he was also a war hero, inter-imperial actor, and charismatic person, incidentally carrying the name of Chinghis Khan and Muhammad at the same time. But as we have seen, in the affairs of Cengiz Mehmed Geray, it was Pazvantoğlu, a regional powerholder without any pedigree, who orchestrated and internationalized the plan. This was very much a story from the age of revolutions, when old pedigree affiliations gained new meanings, and new actors without aristocratic capital played major roles in the political game. Did Cengiz Geray truly believe in the possibility of becoming monarch of a state to be carved out of the Ottoman Empire, which he would rule with Pazvantoğlu? We do not know what he thought of these projects and how he saw his possible role in the global politics of the revolutionary age. We have no evidence that Cengiz Mehmed Geray acted for, or had any aspirations,

129 Rossiiskii gosudarstvennyi istoricheskii archiv, f. 994, op. 2, d. 473, 1, 1-8. Quoted by O’NEILL, “Rethinking Elite Integration,” 403.

130 Ali Yaycioglu, "Révolutions de Constantinople: France and the Ottoman World in the Age of Revolutions," in: French Mediterraneans: Transnational and Imperial Histories, edited by Patricia M.E. Lorcin and Todd Shepard, Lincoln, Nebraska University Press, 2016, 21-51. 
to overthrow or replace the Ottoman power or dynasty. We lack sources in which Cengiz Geray speaks directly to us. Most of the material used to construct his biography comes from scattered official archives that reflect the perspectives and languages of the Ottoman and Russian states. Still, however, no matter what his actual intentions were, his Chingiside credentials inevitably and directly affected how his influence, strength, and possible designs were assessed by his friends and foes. This was certainly a critical factor which distinguished him from the plenitude of other magnates and ambitious local actors in the Ottoman world. But we do know that Cengiz Geray was proud of his Chinghisid pedigree and probably believed that the Ottomans failed to respect it and his service in the war, when they demolished his estate and prohibited him from returning to the village small town of Vyrbitsa. 